\title{
Superlative Sign Typology of Curahan Hati - Harapan Warga Jakarta Political Advertising Video
}

\author{
J Suryono $^{1}$, P I Astuti ${ }^{2}$, N T Rahayu ${ }^{3}$, M Widayati ${ }^{4}$ and Hariyanto ${ }^{5}$ \\ 1,2,3,4,5 University of Veteran Bangun Nusantara, Sukoharjo, Indonesia \\ E-mail: jokowignyo@univetbantara.ac.id
}

\begin{abstract}
The article highlights the meaning construction phenomenon from a political advertising video entitled Curahan Hati - Harapan Warga Jakarta (Confession - Expectation from Jakarta People) through a hyper-semiotics analysis. It aims to describe the hyper-reality sense based on a number of sign typologies, which include proper sign, pseudo sign, false sign, recycled sign, artificial sign, and superlative sign. It adopted a Qualitative method for the study. The data source derived from 41 frames of the political advertising video's scenes that show Jakarta people's daily life. A Content Analysis was deployed as the data collecting technique. The findings revealed that the political advertising video entitled Curahan Hati - Harapan Warga Jakarta had utilized superlative sign domination, as it was designed to create a multiplicity of hyperbolic sense for the sake of political imagery.
\end{abstract}

Keywords : Political Advertisement Video; Confession; Superlative Sign

\section{INTRODUCTION}

General election represents a democratic culture to accommodate the people's sovereignty. It requires direct participation from citizens to vote their favored leaders based on the evaluation of their working performances. The national event encourages the candidates to promote themselves through a political communication platform such as a political advertisement.

The political advertisement contains political messages to persuade and influence citizens' points of view in defining their future leaders. As a form of communication, it offers a strategic role in attracting public interest [1], [2] through a dominant campaign among voters. In general, political parties, legislative candidates, the president and vice president candidates, the governor and deputy governor candidates prefer publicizing their profiles through the advertisements in an attempt to secure a high number of votes[3].

In various forms and styles, political advertising video has turned as the means in propagating candidates' visions and missions for the developing and developed democratic countries. The notion had been explained by [4] as a key message in catching public interest more effectively than conventional media. With the focus on particular issues, it can drive the 
public policy determination and educate people through persuasive contents to improve a positive reputation. Featherstone in [5] stated that commodity messages could even be embedded in the political advertisement's feature through a repetitive association and jointentity which comprises of commodity and significance. The feature eventually underlies a notion of commodity sign that functions as a promoting power in advertising particular objects through imagery.

Therefore, image and appearance become a combination of urgent matters that the political parties should consider in the contemporary lifestyle by attaching a commissive sense. Commodity sign will help them in displaying their best profiles, as the most excellent, enchanting, and helpful parties that could offer the most effective solution to afford social betterment [6].

Marchand in [5] stated that the social reality of advertisement should not be comprehended as an honest and genuine representation due to its distortion and hyperbolic impact. In brief, the signs do not reflect reality as it actually were, however only convey a similar thing that at glance relates to it.

The parody of political advertising video entitled Curahan Hati - Harapan Warga Jakarta from by Toto Lucman is considered containing dishonest elements. It features a distortion and sign selection to present hyperbolic messages through imagery. Figure 1, Figure 2, and Figure 3 point out the parts of political advertisement's distortion:

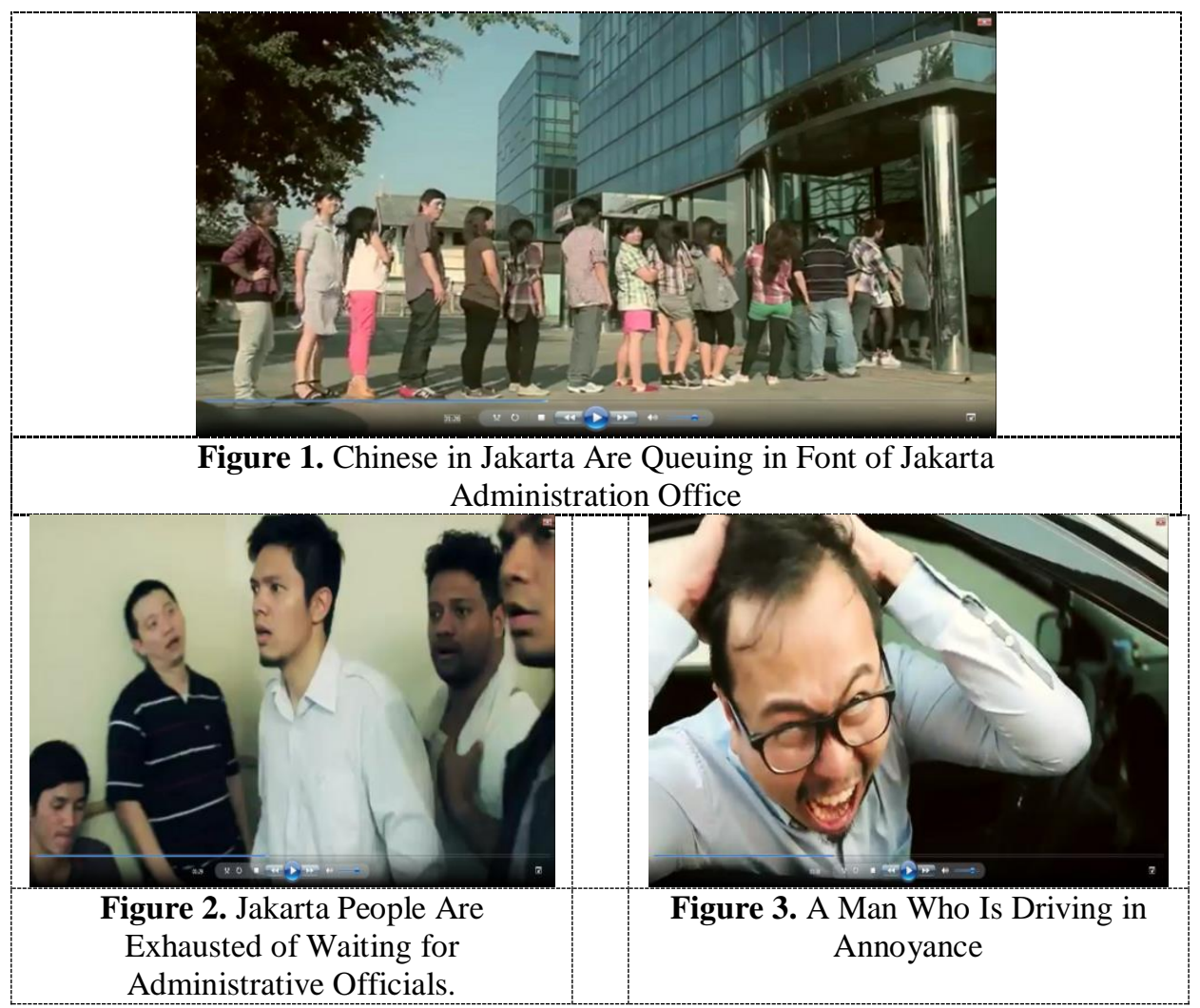




\section{METHOD}

The study adopted a Descriptive Qualitative method. It took the political signs in the scenes of Curahan Hati - Harapan Warga Jakarta political advertising video as the data. In more detail, the data source consisted of 41 frames of scenes from the advertisement showing the Jakarta people's daily life. A purposive sampling technique was considered to pick up the data source, as it could completely embrace the research focus in exploring the signs in the advertisement. Data Collecting Technique

A Content Analysis was deployed as the data collecting technique to effectively note the data source. According to [7]-[9], Content Analysis comprised of several activities, which include scrutinizing, interpreting, and transcribing.

Data Analysis Technique, the analysis utilized a Contextual model in exploring the hypersemiotics signs which include: 1) proper sign, 2) pseudo sign, 3) false sign, 4) recycled sign, 5) artificial sign, and 6) superlative sign[10] to describe the phenomenon presented in the political advertising video. It belongs to an inductive model which consists of data observation; hypersemiotics sign classification through tables; simultaneous interpretation of patterns, theory, secondary data, and context; and conclusion[9].

The first stage of analysis was held by classifying the scenes into two categories which include verbal and nonverbal messages. Meanwhile, the second stage of analysis aims to explain the categories of verbal messages based on the hyper-semiotics sign typology.

\section{RESULTS AND DISCUSSION}

The analysis of data source revealed a message construction of Curahan Hati - Harapan Warga Jakarta political advertising video. Table 1 points out the classification of hypersemiotics signs from the advertisement.

Table 1. Meaning Construction of Curahan Hati - Harapan Warga Jakarta Political Advertising Video

\begin{tabular}{cccc}
\hline No. & $\begin{array}{c}\text { Hyper-sign } \\
\text { Classification }\end{array}$ & Frequency & Percentage \\
\hline 1. & Proper Sign & 1 & 0.02 \\
\hline 2. & Pseudo Sign & 0 & 0 \\
\hline 3. & False Sign & 0 & 0 \\
\hline 4. & Recycled Sign & 13 & 0.56 \\
\hline 5. & Artifisial Sign & 1 & 0.02 \\
\hline 6. & Superlatif Sign & 40 & 0.98 \\
\hline & Number of Frames & 41 & $100 \%$ \\
\hline
\end{tabular}

Table 1 shows the superlative sign domination with the largest portion among all reaching 0.98. Superlative sign remarks a hyper-signification through modulation effects. Through the intensification, improvement, and extremity, it causes reality to become larger than it actually were. 
The advertising video's superlative signs appear in 26 frames that expose the Jakarta people's daily life in regards to the city's public administration services. The frames show several depictions which include: Frame1) a man that practices silat on his bed by jumping, turning around, and changing his clothes with a white t-shirt and jeans; Frame 2) an astonished man for seeing the crowded road; Frame 3) scuffle in the roadside; Frame 4) limited road access due to the scuffle; Frame 5) an anxious car driver for the traffic jam; Frame 6) an upset cart puller for the traffic jam; Frame 7) an upset motor rider for the traffic jam; Frame 8) an upset car driver; Frame 11) a dizzy motor rider; Frame 12) a stressed-out car driver that holds his head; Frame 13) an annoyed man that shows three fingers as a code to tell viewers that he has taken a three-hour trip from home to the administration office; Frame 14) four astonished people for seeing long queue in front of the administration office; Frame 15) people feel tired of waiting for their turns in the administration office - they judge the city's mess due to the Government's ignorance in improving the public service quality; Frame 16) people read newspapers while queuing; Frame 17) people flutter themselves due to the heat and sweat; Frame 18) people throw away the newspapers to show their annoyance; Frame 19) an administrative official appears with his thick mustache and in fierce face; Frame 20) complicated quarrel between a man and the administrative official; Frame 21)an administrative official gives a code to ask levy for the services; Frame 22) a man tries to pick up money from his pocket however finds nothing; Frame 23) people are worried and confused; Frame 24) people gawk for failed gaining services from the officials; Frame 25) people droop and weep; Frame 26) people get mad for the poor services; Frame 27) people complain and give up; Frame 28) people feel disappointed for the illegal levies; and Frame 29) people expect Mas Jokowi to overcome the city's problems which include traffic jam, slums, illegal levies, corruption, and poverty.

\section{CONCLUSION}

The study generates two main conclusions, which include:

The scenes of Curahan Hati - Harapan Warga Jakarta political advertising video had pointed out superlative sign domination to create a multiplicity effect through its hyperbolic sense for the sake of imagery. The sign functions to depict the fact in more appealing features than its actual condition by utilizing technologies in conveying an extreme narration through signs and visual elements. In the political advertisement, superlative signs present a special side of the candidates' profiles. However, the signs reflect a dishonest reality through the distortion, thus garners negative critics in term of ethical codes [11]. The political advertising video is able to persuade the public in giving their decision, however it is urgently demanded to prioritize the truth and credibility[12], [13].

The current society has been capable to evaluate their candidates' performance and become more critical in judging the political imagery. As [14] explained that the society had understood the essence of voting, to which they should not only put consideration to their future leaders' physical appearance, but also comprehend that the impact of reality distortion would potentially drag to an identity crisis since the hyperbole could only remain a fiction.

The political advertising video entitled Curahan Hati - Harapan Warga Jakarta indeed contains a negative connotation that could lead to a racial issue in its scene that shows a long queue in the administration office, of which Chinese are briefly exposed as the second-class residents that have limited access to the public services. The phenomenon depiction is similar to the political discrimination for the black people that was ever happened in the United States. 
It also implies an anti-multiculturalism which is similar to David Perryman's political advertising video that implicitly opposed J. C. Watts by speaking out the term Afro as a means to create a negative association of black people's life who were often distinguished as lowerclass society, criminals, and militant of black power movement [15].

\section{REFERENCES}

[1] M. Moke, "Political Advertising in Chile," in The SAGE Handbook of Political Advertising, Thousand Oaks, CA: SAGE Publication, 2006.

[2] L. L. Kaid, Handbook of Political Communication Research. London: Routledge, 2004.

[3] Sumbo Tinarbuko, "Menakar Iklan Politik Pemilu 2009," Nirmana, vol. 11, no. 2, pp. 114-124, 2009.

[4] K. M. Lancendorfer, "The role of attributions on voter response to political advertising," in American Academy of Advertising Conference Proceedings, 2006, p. 33.

[5] R. Noviani, Jalan Tengah Memahami Iklan. Yogyakarta: Pustaka Pelajar, 2002.

[6] J. Harms and D. Kellner, "Toward A Critical Theory of Advertising," Curr. Perspect. Soc. theory, vol. 11, pp. 41-67, 1991.

[7] Sudaryanto, Metode dan Aneka Teknik Analisis Bahasa: Pengantar Penelitian Wahana Kebudayaan Secara Linguistis. Yogyakarta: Sanata Dharma University Press, 2015.

[8] D. E. Subroto, Pengantar Metoda Penelitian Linguistik Struktural, 1st ed. Surakarta: UNS Press, 1992.

[9] R. Santosa, Metode Penelitian Kualitatif Kebahasaan, 1, April 2 ed. UNS Press, 2017.

[10] Y. A. Piliang, Semiotika dan Hipersemiotika: kode, gaya dan matinya makna. Bandung: Jalasutra, 2010.

[11] D. S. Waller, "Advertising agency-client attitudes towards ethical issues in political advertising," J. Bus. Ethics, vol. 36, no. 4, pp. 347-354, 2002.

[12] C. Atkin and G. Heald, "Effects of Political Advertising," Public Opin. Q., vol. 40, no. 2, p. 216, 1976.

[13] S. Udeze and U. Akpan, "The Influence of Political Advertising on Nigerian Electorate," J Commun., vol. 4, no. 1, pp. 49-55, 2013.

[14] E. I. Nabella, "Tinjauan Semiotika Komunikasi Visual Iklan Caleg Superman (Studi Kasus Iklan Politik Caleg Superman Pada Website Caleg Superman Tahun 2014)," DeKaVe, vol. 8, no. 1, pp. 11-18, 2015.

[15] C. D. Mcilwain, "Race, pigskin, and politics: A semiotic analysis of racial images in political advertising," Semiotica, no. 167, pp. 169-191, Jan. 2007. 